\title{
Farms and gardens everywhere but not a bite to eat? A critical geographic approach to food apartheid in Salt Lake City
}

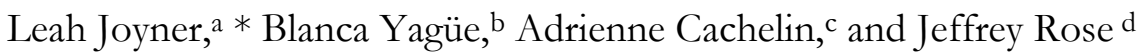 \\ University of Utah
}

\begin{abstract}
Submitted January 17, 2021 / Revised May 31, July 27, August 8, October 5, and November 3, 2021 /
Accepted November 9, 2021 / Published online February 24, 2022

Citation: Joyner, L., Yagüe, B., Cachelin, A., \& Rose, J. (2022). Farms and gardens everywhere but not a bite to eat? A critical geographic approach to food apartheid in Salt Lake City. Journal of Agriculture, Food Systems, and Community Development, 11(2), 67-88. https://doi.org/10.5304/jafscd.2022.112.013
\end{abstract}

Copyright (C) 2022 by the Authors. Published by the Lyson Center for Civic Agriculture and Food Systems. Open access under CC-BY license.

\author{
Abstract \\ Through community-engaged research, we investi- \\ gate how political and economic practices have cre- \\ ated food apartheid and the ways in which this \\ legacy complicates efforts toward equitable urban \\ agriculture in Salt Lake City (SLC). The study takes \\ place in SLC's Westside, where an ample number \\ of farms and gardens exist, yet food insecurity is a \\ a* Corresponding author: Leah Joyner, Ph.D. Candidate and \\ Graduate Teaching and Research Assistant; Department of \\ Parks, Recreation, and Tourism; Environmental and \\ Sustainability Studies Program, University of Utah; 270 South \\ 1400 East Room 201, William A. Stewart Building; Salt Lake \\ City, UT 84112 USA; +1-252-531-1544; leah.joyner@utah.edu \\ b Blanca Yagüe, Ph.D. Student and Graduate Teaching and \\ Research Assistant, Department of Anthropology, University \\ of Utah; blanca.yague@utah.edu \\ c Adrienne Cachelin, Ph.D., Professor, Environmental and \\ Sustainability Studies Program, University of Utah; \\ adrienne.cachelin@health.utah.edu \\ d Jeffrey Rose, Ph.D., Assistant Professor, Department of \\ Parks, Recreation, and Tourism, University of Utah; \\ jeff.rose@utah.edu
}

persistent issue. We partner with a small urban CSA farm operating in a USDA-designated food desert in SLC's Westside to explore the farmers' own questions about whom their farm is serving and the farms' potential to contribute to food justice in their community. Specifically, we examine (1) the member distribution of this urban CSA farm and (2) the underlying socio-political, economic, and geographic factors, such as inequitable access to land, housing, urban agriculture, food, and transportation, that contribute to this distribution. GIS analyses, developed with community partners, reveal spatial patterns between contemporary food insecurity and ongoing socioeconomic disparities matching 1930s residential redlining maps. These data resonate with a critical geo-

\section{Funding Disclosures}

This work is a part of a project that has been supported by research funding from the University of Utah iNterdisciplinary EXchange for Utah Science (NEXUS) Pilot Grant Program; The University of Utah Sustainable Campus Initiative Fund; and a Slow Foods Utah Microgrant. The authors have no conflict of interest to declare. 
graphic approach to food apartheid and inform a need for deeper and more holistic strategies for food sovereignty through urban agriculture in SLC. While resource constraints may prevent some small farmers from attending to these issues, partnerships in praxis can build capacity and engender opportunities to investigate and disrupt the racial hierarchies enmeshed in federal agricultural policy, municipal zoning, and residential homeownership programs that perpetuate food apartheid.

\section{Keywords}

Food Apartheid, Urban Agriculture, Redlining, Food Justice, Critical Geographies of Food, Food Deserts, Community-Based Praxis

\section{Introduction}

In Salt Lake City (SLC), food insecurity is a persistent issue, despite a multitude of food access advocacy programs and a vibrant tradition of urban agriculture (UA). This paradox is evident in SLC's Westside, home to much of the city's immigrant and refugee community, including $75 \%$ of SLC's Latinx population (University Neighborhood Partners, 2019). In the Westside, spatial clusters of food insecurity have been designated by the USDA as 'food deserts' (Food Access Research Atlas, 2021a), a label that does not capture the myriad political and economic factors that undergird structural food inequity or the particularities of place (Holt-Giménez \& Harper, 2016).

A great deal of food is grown in local backyard and community gardens and small urban farms in SLC's Westside (Yagüe et al., 2020). Urban farmers cite more affordable land prices and larger residential tracts as primary reasons for living in and growing food in this part of the city. This is particularly salient in the Glendale neighborhood, where there are multiple small farms in operation, a large cohousing development with residential gardens, and numerous residents who cultivate gardens and manage animal husbandry systems. Additionally, food culture is strong in this community, where many residents identify foodways and practices connected to traditional foods, cultural identity, and community building (Cachelin et al., 2019). This complexity demonstrates some of the reasons that so-called food deserts may be better under- stood as products of food apartheid. A food apartheid framework accounts for the idea that food inequity is not a natural occurrence based in ecological limits, but rather an explicit outcome of political economy based in structural racism and unequal geographies of access (Reese, 2019; Brones, 2018). The political and economic factors that underly food apartheid may also provide context for the prevalence of food insecurity in the face of abundant local urban agriculture.

One farm in SLC's Glendale neighborhood operates from a self-described progressive and radical-leaning food paradigm that drives their goal of practicing food justice through UA. This community supported agriculture (CSA) farm has a unique land access model, growing food in neighbors' backyards and, in exchange, providing landowners with a weekly share of produce during the growing season. The farm name, Backyard Urban Gardens (B.U.G. Farms), reflects this approach. This structure allows the farmers to operate the CSA despite not owning the land, which alleviates a significant barrier for localized agricultural operations.

The researchers initially visited B.U.G. Farms in 2017 as a part of a more extensive collaborative effort to understand food access and justice in SLC. During this initial field visit, the farmers expressed concern about the possibility that they may be exporting produce from the Westside to predominately white, affluent neighborhoods elsewhere in the city. In further conversations with our team, the farmers expressed a desire to understand their own positionality within their neighborhood and the patterns of food inequity they have noticed across SLC.

This article describes our resulting communityengaged research partnership and details our collective exploration into the underlying political and economic factors that contribute to food apartheid in SLC and complicate B.U.G. Farms' aims to practice food justice. First, we seek to answer the farmers' own questions regarding the actual demographic and geographic composition of this urban CSA operating in a U.S. Department of Agriculture (USDA)-designated food desert in SLC's Westside, and to what extent the CSA might be exporting produce to other communities and thus undermin- 
ing its own goals of food justice. Subsequently, we employ a critical geographic lens to examine political and economic factors, such as racially inequitable access to land ownership, food, and transportation that might account for these distributions. We draw on a variety of data, including CSA owner and member surveys, community interviews, historic geographic data, and contemporary census data to spatially contextualize the structural processes that undergird food apartheid in SLC. We then consider the complex role of collaborative research praxis towards informing deep and holistic approaches to food sovereignty through UA.

\section{Context and Community-Based Praxis}

Over the past four years, we have engaged in community-based praxis with our partners at B.U.G. Farms toward understanding how the sociopolitical context of the food system shapes the farm and its potential and actual relationship to the community. At the time of our initial site visit, one member of the research team resided at a home where B.U.G. Farms grows food, which uniquely positioned our team to launch a collaborative partnership and support B.U.G. Farms' aims to explore options to better connect with and positively affect their community. In our earliest conversations with B.U.G. Farms, the farmers situated their concerns about whom their CSA was serving within their broader feelings of hopelessness about the potential impact of one small farm in the face of a global corporate, industrial, foodscape and locally inequitable urban foodscape. These conversations launched our resulting partnership rooted in community-based praxis. For our team, community-based praxis means that work occurs as a partnership with a lateral exchange of benefits, is driven by the aims of the researchers and the community, and carries the commitment to ensure that data collected are used to inform actionable outcomes (Community Research Collaborative, 2021; Torre et al., 2018). Community-based praxis guides our aims to avoid extractive, ahistorical, and nonpolitical approaches that have traditionally characterized social science and ecological research (Tuck, 2009). Our praxis has taken shape through a blend of critical conversation, action, and outreach as we have joined B.U.G. famers in harvesting and sharing produce, distributing seedlings at community events, and engaging with Westside residents to understand their visions for the farm's role in the neighborhood foodscape.

The subsequent literature review contextualizes these conversations and what we have learned through our collaborative community outreach by exploring the complex factors that B.U.G. farmers, CSA members, and Westside residents have pointed to from their own perspectives as underlying the local foodscape. Specifically, we examine how myriad global conditions inherent to the industrialized food system (1) set the stage for widespread food insecurity; (2) intersect with municipal factors such as housing inequality, food access programs, land-use policies, and gentrification to produce racially inequitable access to food; and (3) complicate the possibilities for urban farmers who seek to play a role in food justice.

\section{Big Food and the Foundations of Food Insecurity}

Small and urban farms operate as spaces of contestation and possibility within the complex setting of the industrialized food system, which we refer to here as Big Food. Big Food is characterized by mechanized large-scale and monoculture production, overreliance on extractive petrochemical inputs, intensive water usage, genetically modified seeds, and heavily subsidized immigrant labor (Alkon \& Agyeman, 2011; Neff et al., 2009; Hoffpauir, 2009; Manning, 2004). The propulsion of Big Food necessitates global dependency on commodity crops, which is facilitated by corporate interests embedded in the state who influence governmental subsidies and global markets (Friedman, 1993; McMichael, 2009). Proponents of Big Food employ the rhetoric of scarcity and famine to contend that industrialization is the only way to feed an ever-growing population. However, research indicates that small farms can produce higher quality and quantities of food on smaller, more intensively managed parcels of land, foster greater levels of biodiversity than industrial counterparts, and support increased food systems resilience (Altieri, 2008; Manyise \& Dentoni, 2021; Ricciardi et al., 2021; Shiva, 2005).

Big Food is buoyed by governmental policies that both hide and externalize the true costs of 
food such that small farmers are unable to compete in the marketplace (Windham, 2007). For example, international neoliberal policy and labor programs such as the North American Free Trade Agreement (NAFTA), Central America Free Trade Agreement (CAFTA), and the U.S.'s H-2A immigration program enable Big Food to generate an underpaid and precarious agricultural workforce with limited access to organized labor rights advocacy (Sbicca et al., 2020). These types of trade policies, also referred to as immigrant subsidies, enable commercial growers to hire 'guest workers' to enter the U.S. for agricultural work, and have been widely criticized for labor rights abuses of immigrant workers akin to modern-day slavery (Bauer \& Steward, 2013; Coalition of Immokalee Workers, 2020). In the U.S., small farms, defined by the USDA as farms with under US $\$ 350,000$ in annual sales, do not receive proportionate rates of federal subsidies compared to larger, industrial operations (Bekkerman et al., 2019; USDA Economic Research Service [USDA ERS], 2020). The distribution of labor subsidies exacerbates a situation in which small farmers who do not participate in exploitive governmental labor programs, and are not otherwise supported by subsidies, must charge higher prices than their commercial counterparts to offset the resource constraints of small-scale, laborintensive food production (Bekkerman et al., 2019; Cross, 2020).

The skewed distribution of agricultural subsidies not only serves to maintain inequity in labor relations but also presents serious implications for food access. The prevalent undervaluation of agricultural labor in the U.S. is connected to the staggering rates of people who work growing food in this country who also experience food insecurity, a state of unreliable access to safe and nutritious food (Brown \& Getz, 2011; Reno, 2020). Concerns relating to the distribution of federal funding through agricultural subsidies and food access programs were raised in our conversations with B.U.G. farmers and neighboring farmers, many of whom noted that the struggle that small farmers face to feed themselves can also preclude their participation in local initiatives to alleviate food insecurity.

Food insecurity is so widespread in the U.S. that 1 in 7 people regularly uses food banks, and 14.3 million households are food insecure (Feeding America, 2020). Food insecurity also disproportionately affects Black, Indigenous, and people of color and LGBTQ+ people (Holt-Giménez, \& Harper, 2016; Lemke \& Delormier, 2018; Leslie, Wypler, \& Bell, 2019; Reese 2019). Federally funded response to U.S. food insecurity is largely based on the Supplemental Nutrition Access Program (SNAP), formerly referred to as food stamps, in which $11.3 \%$ of total U.S. households are enrolled (U.S. Census Bureau, 2020). SNAP participants redeem $83 \%$ of total benefits at superstores, $6 \%$ at grocery retailers, and $5 \%$ at corner stores (Center on Budget and Policy Priorities, 2019). While SNAP is the primary mechanism through which the government responds to food insecurity, the majority of benefits ultimately goes back to the corporate beneficiaries of Big Food via sales and subsidized food access for those corporate conglomerates' own underpaid employees (Ayazi \& Elsheikh, 2016). The structure of the SNAP program creates a feedback loop in which the corporations that contribute to food insecurity in the first place benefit from the governmental programs purportedly designed to alleviate hunger.

One of the primary avenues for small and urban farms who, like B.U.G. Farms, are seeking to respond to food insecurity is through joining the growing number of farmers markets accepting SNAP benefits. However, even when markets successfully navigate the cumbersome process of obtaining the necessary approval and technology for SNAP, high costs, lack of transportation, and an overrepresentation of whiteness in the cultural organization of market spaces remain barriers for low-income and marginalized customers (Alkon \& McCullen, 2010; Hoover, 2013; Kellegrew et al., 2018; Larimore, 2018). The amount of funding spent at farmers markets through SNAP remains a very small portion of overall expenditures (Farmers Market Coalition, 2020). In order to increase urban accessibility to local food, we must first reckon with the impact of U.S. governmental response to food security from the root causes, such as systemic disparity in income, access to land, transportation, and purchasing power among food-insecure individuals. 


\section{Food Apartheid: Racialized Food Insecurity}

Small and urban farms, such as B.U.G. Farms, who seek to understand issues of food access are confronted with the task of first understanding the shape of food insecurity in their own communities. In efforts to conceptualize widespread food insecurity, the USDA categorizes some areas as 'food deserts,' which denotes inadequate and inequitable food access (USDA ERS, 2021a; Olson, 2018). Food deserts are defined as census tracts wherein "at least 500 people or 33 percent of the population [is] located more than 1 mile (urban) or 10 miles (rural) from the nearest supermarket or large grocery store" (Dutko et al., 2012, p. 6) The food desert designation is a highly contested, deficitoriented framework, which devalues existing community foodways such as small, independently owned corner stores, backyard gardens, and foodsharing networks, and does not adequately account for the socio-geographic factors that influence food availability (De Master \& Daniels, 2019; Penniman, 2018; Raja et al., 2008; Reese, 2019; Taylor \& Ard, 2017; Brones, 2018). 'Food swamp' is another designation for areas where fresh food availability is scant but where fast food and highly processed foods are widely available (CookseyStowers et al., 2020; Fielding \& Simon, 2011; Rose et al., 2009). The food desert and food swamp designations can result in the framing of marginalized communities, especially communities of color, as hostile environments, superimposing narratives of damage and concealing the processes of capitalism and colonialism that create clustered food (Lewis, 2015; McClintock, 2018; Shannon et al., 2013). Food swamp and desert designations also conjure imagery of naturally occurring landscapes rather than the reality that food inequity is actively produced and maintained by systems and processes (Reese, 2019).

The food desert and swamp designations presuppose supermarket access as the most appropriate remedy for food insecurity given that, in the Food Access Research Atlas (USDA ERS, 2021b), "low access to healthy food is defined as being far from a supermarket, supercenter, or large grocery store (para. 2). The USDA approach to defining supermarkets as the solution for food insecurity is especially troubling when considered in conjunc- tion with the history of supermarket redlining. Supermarket redlining is a phenomenon in which major chain supermarkets relocate stores from inner cities or low-income neighborhoods to suburbs, citing lower profit margins and higher operating expenses (Eisenhauer, 2001; Zhang \& Ghosh, 2016).

Supermarket redlining stems from the more widely recognized practice of residential redlining through which federal lending programs incentivized white homeowners' disinvestment in urban centers while simultaneously preventing ethnic minorities from obtaining homeownership. This practice of residential segregation through redlining was implemented in 1933 by the Homeowners Loan Corporation (HOLC) under the oversight of the Federal Home Loan Bank Board. The HOLC generated a series of residential security maps that segmented cities into sections ranked in terms of viability for home loans. Sections designated "A" were considered to be the "best" areas for investment in home loans, "B" areas were "still desirable," and "C" areas were "definitely declining." African American neighborhoods, or areas that were home to "low-class foreign-born laborers," were assigned a "D" grade, which denoted "hazardous" areas not viable for home loans (McClintock, 2011; Nelson \& Ayers., 2020). Redlining resulted in geographically concentrated clusters of racialized poverty. Consequently, many food retailers intentionally pulled stores out of lowincome inner-city neighborhoods (Eisenhauer, 2001; Zhang \& Ghosh, 2016), setting the stage for geographically based, racialized food access issues. While white, middle-class Americans amassed intergenerational wealth through equity in their owned homes, African Americans and people of color were actively prevented from accessing home loans in all sectors of the HOLC maps and the suburbs (Rothstein, 2017). Redlining was not prohibited until 1968, and its impacts continue to contribute to racially inequitable housing insecurity and food availability in major cities across the U.S. (Eisenhauer, 2001; McClintock, 2011; Nelson \& Ayers, 2020; Rothstein, 2017).

Contemporary census data reflect that USDAdesignated food desert tracts are more likely to be located in communities of color and in areas with 
higher rates of poverty than nonfood desertdesignated tracts in the same cities (Dutko et al., 2012). In a systematic review of food desert literature, Walker et al. (2010) cite multiple findings indicating that predominately Black and Latinx communities have less access to supermarkets and healthy food options than predominately white neighborhoods. This arrangement is not only due to a lack of supermarket access but also transportation, which is often scarce in USDAdesignated food deserts and is a primary barrier to procuring fresh, healthy, and affordable foods (Dutko et al., 2012; MacNell et al., 2017; Strome et al., 2016).

People who are affected by food insecurity also more frequently experience a lack of access to housing, healthcare, and fair wages (Gaines-Turner et al., 2019; Kirkpatrick \& Tarasuk, 2011; Raskind, 2020; Wolf-Powers, 2017). An Urban Research Institute study found that renters struggle with food insecurity at much higher rates than homeowners and are often forced to choose between paying for rent or food (Karpman et al., 2018). Renting can also prevent other forms of adaptation to food insecurity, such as home gardening (Mee et al., 2014). The structural foundations of food insecurity stem from political and economic legacies of racially inequitable access to housing, transportation, fair wages, and other socioeconomic determinants of health.

A growing number of food scholars and activists assert that food apartheid is a more appropriate label for this systematic production of food inequity, as it calls into question the ways in which socio-political factors related to race and class shape communities' relationships with food (HoltGiménez \& Harper, 2016; Penniman, 2018; Reese, 2019; Sbicca, 2012; Brones, 2018). Conceptually, food apartheid is a term that "forces us to question ... the ways non-profits, advocates, researchers, and policymakers frame residents' lack of knowledge or will to access or eat healthier foods, rather than locating the deficiencies in the ways white supremacy has shaped neighborhood food spaces" (Reese, 2019, p. 46). Food desert and food swamp labeling naturalize and thus normalize, whereas food apartheid describes the many factors that created and continue to shape inequity and maintain racial hierarchies throughout the food system (Holt-Giménez \& Harper, 2016).

\section{Food Justice, Sovereignty, and Urban Agriculture} Urban agriculture is rooted in a rich history of food justice advocacy led by farmers and people of color and can serve as an essential component of movements toward the disruption of food apartheid (Agyeman \& McEntee, 2014; Alkon \& Norgaard, 2009; Corcoran, 2021; Gripper, 2020; Heynen, 2009; Penniman, 2018; Whyte, 2017). Food justice can be defined as "the right of communities everywhere to produce, process, distribute, access, and eat good food regardless of race, class, gender, ethnicity, citizenship, ability, religion, or community" (Institute for Agriculture and Trade Policy, 2012, p. 1). Urban farms, such as B.U.G. Farms, who seek to practice justice-oriented UA may also consider themselves participants in, or supporters of, the food sovereignty movement.

Food sovereignty offers an oppositional strategy to food apartheid, which includes the commitments of food justice advocacy as part of a strategy broader in scope that advances the democratization of the food system by situating the right to democratic control of the entire food system, from production to consumption, with people rather than corporations (Holt-Giménez, 2009; MartínezTorres \& Rosset, 2010). Food sovereignty has been defined as "the right of peoples to healthy and culturally appropriate food produced through ecologically sound and sustainable methods, and their right to define their own food and agriculture systems" (Nyéleni, 2007, p. 7). Food sovereignty is both a paradigm and process, predicated on a radical approach to the active dismantling of the larger racialized system in which small-scale and urban agriculture are made inaccessible from both producer and consumer ends of the value chain (HoltGiménez \& Shattuck, 2011).

The history of racism embedded in U.S. agricultural policies has culminated in an overwhelming disenfranchisement and displacement of Indigenous, Black, and people of color throughout the agricultural sector and especially as farmers (Ayazi \& Elsheikh, 2016; Elsheikh, 2016; Fagundes et al., 2020; Penniman, 2018; Tyler \& Moore, 2013). The preventative nature of land ownership 
is a persistent barrier that renders UA largely inaccessible to low-income and other disadvantaged community members in the U.S. (Horst et al., 2017; Siegner et al., 2018; Wekerle \& Classens, 2015). The necessity to procure affordable and stable land access often leads urban farmers to seek out low-cost tracts of land, which tend to be more available in marginalized areas that are already vulnerable to gentrification (Sbicca, 2020). The repercussions of redlining underly this cycle, as property values are frequently lower in USDA-designated food deserts compared to non-food redlined urban neighborhoods (McClintock, 2011; Reese, 2019). This dynamic can exacerbate food apartheid when UA attracts renewed interest in development and inadvertently drives up property values in marginalized communities or USDA-designated food deserts (Jettner, 2017; McClintock, 2018; Pride, 2016; Reynolds \& Cohen, 2016; Sbicca, 2019). The resulting cycle of eco-gentrification presents a negative feedback loop, in which UA is a critical tool for food sovereignty and yet may amplify persistent barriers to food security, land access, and agricultural resources for Black, Indigenous, and people of color who are the most affected by food apartheid (Sbicca, 2020). Negative impacts of UA, such as eco-gentrification, may be linked to the prevalence of inequality and barriers to financial security, leaving many producers struggling to pay themselves a living wage and with little time to also attend to issues of food justice in their own communities.

The perpetuation of food apartheid in urban environments is related to a number of structural factors such as colonization, whiteness, and privilege embedded in the food system, which predicate barriers to addressing food security through alternative food provision and can complicate the relationship between small farms, food justice, and food sovereignty (Anguelovski, 2015; Guthman 2008a, 2008b; Hoover, 2013; Slocum, 2007). Such is the case with B.U.G. farmers, who seek to support food justice in their community while also attaining financial viability and living wages in a marketplace dominated by Big Food. Recognizing these complexities drives the intentions of our community partners and informs our collaborative critical geographic approach to understanding the actual construction of food apartheid and associated relationships with UA in SLC.

\section{Study Site}

The development of Salt Lake City's food justice movement has not been as widely studied as in other U.S. cities that have become well known for locally driven food movements, such as Denver, Oakland, Philadelphia, Baltimore, New York, and Chicago. In many of these cities, scholars have identified connections between urban agriculture projects and negative outcomes such as ecogentrification and the perpetuation of overt whiteness in local food movements (Alkon et al., 2019; Alkon et al., 2020; Hoover, 2013; Jettner, 2017; Kellner, 2016; McClintock, 2018; Pride, 2016; Sbicca, 2019). As the local food movement in SLC continues to grow, it is well poised to incorporate lessons learned in similar contexts by incorporating food justice and sovereignty in urban agriculture development at an earlier stage in order to avoid replicating cycles of food apartheid and displacement via UA.

This study takes place in SLC's Westside, where political and economic legacies of inequality are prevalent, including clusters of extractive industries and associated point-source pollution, the construction of railway and highway systems that separate the neighborhood from the rest of the city and impede food access, and increasing development-driven displacement (Carothers, 2018; McKellar, 2015; Mullen et al., 2020; SLC Planning Commission, 2014; Tucker, 2019). We focus specifically on the Glendale neighborhood, which shares characteristics with many marginalized urban communities in the United States. It has an ethnic minority rate of $89 \%$ and the largest refugee population in the state of Utah (Salt Lake City Schools, n.d.). In this community, $90 \%$ of schoolchildren qualify for free or reduced lunch, which indicates widespread food insecurity in a setting where food-related disease disproportionally affects Black, Hispanic, and American Indian and Alaska Native populations in SLC (Salt Lake County Health Department, 2017).

Preliminary fieldwork in Glendale, a USDAdesignated food desert, indicates that many food access organizations operating here have not suffi- 
ciently aligned their programs with the needs of residents. Many SLC organizations have employed charity-based frameworks in food access programs. Charity-based programs attend to the surface-level symptom of hunger by relying on donation-driven food distribution, which can perpetuate inequality in the food system and normalize charity rather than societal change as a response to povertydriven food insecurity (Fisher, 2017; Poppendieck, 1999). In SLC, charity-based approaches to food insecurity alleviate the immediate issue of food insecurity for some residents, yet may also be precluding authentic connections between local food producers and community members (Yagüe et al., 2020). Racially inequitable access to food remains a persistent issue here, and political-economic factors of inequality impede the relationship between UA and food justice.

\section{Methods: A Critical Geographic Approach to Food Apartheid}

Critical geographic methods are particularly well suited to the analysis of political economic factors that undergird food apartheid. Critical geographies of food embrace dynamic understandings of spatial processes, allowing for the production of rich descriptive accounts through which we understand a sense of place as the coalescence of multiple "spatially diffused social networks" (Bosco \& JoassartMarcelli, 2018, p. 541). Understanding localized political economy factors can help establish mechanisms for restructuring food systems and support efforts for justice in local and far-reaching contexts (Reynolds \& Cohen, 2016; Trauger, 2017). For example, interviews and surveys with residents can center the lived experiences of racially minoritized populations, including the use of archival information such as historic redlining maps to document systemic forces of racism that create food apartheid (Reese, 2019). Additionally, critical geographies of food can employ participatory and archival methodologies, including interviews, review of policy documents and reports, and participation in food system activism and policymaking (Reynolds $\&$ Cohen, 2016). These dynamic and engaged methodologies enable researchers to describe structural oppressions relevant to UA accurately and ground their analysis in community-based experi- ence. Critical geographies of food can also reveal connections between land tenure, food regimes, and municipal planning systems to expose food injustice and offer the potential for justice-oriented foodways (Tornaghi, 2014).

Following this tradition, we employed a critical geographic approach to better understand how underlying socio-political, economic, and geographic factors are a backdrop for B.U.G. Farms' export of food from a USDA-designated food desert in SLC's Westside. Considering that historic redlining and an enduring lack of access to housing, transportation, and fair wages have all been linked to ongoing structural food inequity (De Master \& Daniels, 2019; Gaines-Turner et al., 2019; Raskind, 2020; Wolf-Powers, 2017), this study draws on various forms of socio-political, economic, and geographic data.

First, to understand the extent of B.U.G. Farms' food export from a USDA- designated food desert, we developed surveys to document the distribution and demographics of B.U.G. Farms' stakeholders. CSA member data were collected in partnership with B.U.G. Farms through an anonymous online survey sent to all CSA members $(\sim 130)$ through the farm's newsletter in fall 2017. The newsletter has a high readership, as it is circulated to all members via email each week to describe the contents of the CSA boxes, provide recipe suggestions and farm updates, and share reminders about delivery and pick-up logistics. The survey was promoted three times in this weekly newsletter and through a printed note that was included in all CSA boxes for one delivery. The survey was designed together by the research team and the farmers, and several questions were adapted from a previous survey of CSAs in the Mid-Atlantic region (Oberholtzer \& Project, 2004). There were 20 total questions, including seven demographic questions: neighborhood and/or zip code of residence, age, gender, racial and/or ethnic identity, place of origin, estimated annual income, and highest level of formal education. The survey also included questions proposed by the farm's operators to gather feedback on the CSA's quality, quantity, and member satisfaction, as well as several additional open-ended questions designed to provide a more qualitative understanding of CSA 
members' motivations and involvement with food movements. As incentive for survey participation, the farm offered one extra box of winter produce through a random drawing for participants. CSA members' locations were mapped in a series of figures that depict members' geographic distribution across SLC and respond to farmers' questions regarding their potential export of food from the Westside.

Secondly, to further explore underlying political and economic factors in the urban foodscape in SLC, we utilized ARC GIS (version 10.8.1) to contextualize how historic redlining spatially overlaps with contemporary inequities in land access, housing, transportation, and food. We generated a series of maps to provide spatial context for understanding our farmer partners' perspectives of how underlying inequities complicate their aims of practicing food justice in SLC. These maps use data from HOLC redlining maps of SLC (Cooley 2018; Nelson \& Ayers, 2020), U.S. Census tract racialethnic and socioeconomic data (U.S. Census Bureau, 2018), public transit information (Utah Transit Authority, 2020), and USDA food desert maps (Food Access Research Atlas, 2021a). Using ArcGIS, historic HOLC redlining districts were mapped onto current SLC census tracts, and data from the U.S. Census Bureau American Community Survey (2018) were used to demonstrate racial and ethnic distributions. Shapefiles from the USDA Food Access Research Atlas were included to represent the location of USDA-designated food deserts within SLC boundaries; these data were also used to represent areas categorized as low income. UTA TRAX (light rail), Frontrunner (commuter rail), and bus routes were also imported and displayed through ArcGIS. The resulting figures depict CSA food distribution in the context of contemporary access to food, transportation, and housing, along with historic residential redlining maps, in order to visually demonstrate how these spatial relationships change over time.

\section{Trustworthiness}

Triangulation, or the cross-examination of data at multiple points, supports the trustworthiness of a study's findings and the overall quality of the research process (Denzin, 1978; Rose \& Johnson,
2020; Savin-Baden \& Major, 2013). We triangulated through the inclusion of various types of historic, social, and empirical data guides our critical geographic approach to understanding factors that underlie food apartheid and associated relationships with UA in SLC. Spatial data points are represented through the mapping of CSA member demographic and geographic distributions. Temporal data range from the 1930s, when redlining was established, to 2018, where contemporary socioeconomic data is juxtaposed against historic redline zones. The persistent nature of unequal geographies of access is depicted through the inclusion of USDA food desert data and SLC transportation maps.

\section{Findings}

A total of 35 shareholders responded to the CSA member survey, or about $27 \%$ of the 130 total shareholders. B.U.G farmers reported that this was the highest response rate ever received in any of their previous CSA satisfaction and feedback surveys. The large majority of respondents $(n=33) \mathrm{did}$ not reside in Westside neighborhoods. Of the two shareholders who did, one is a landowner who received a share in exchange for leasing their land to the farm, and the other is a farmworker who receives a workshare. Previous fieldwork and insights from B.U.G. Farms indicate that the two shares that stayed in the Westside via landowner and worker exchanges represent relatively recent transplants to the area who relocated to and recently purchased land in the neighborhood for the potential to participate in UA and are likely not experiencing food insecurity.

As predicted by the farmers, the majority of CSA shareholders self-identify as white $(n=31)$. One shareholder self-identified as Hispanic. Four participants did not respond to this open-ended question. The CSA farm's owners, landowner partners, and workers all self-identified as white. B.U.G. farmers indicated that these results are consistent with their own understanding of the demographics of CSA members, based on their personal interactions with members through recruitment and distribution processes.

Figure 1 demonstrates that CSA shareholders are located primarily in neighborhoods that are not 
USDA-designated food deserts. This figure depicts the export of locally grown food from foodinsecure Westside neighborhoods to more affluent and food-secure areas of the city and is related to the tension between the small farmers' desires to support equitable access to food and the conditions in which they must charge a higher price in order to afford land and a living wage.

Figure 2 demonstrates that CSA shareholders are more commonly located in areas that were designated " $A$ " and " $B$ " by the HOLC. This figure visually represents how the legacies of discrimination, such as racially driven policies that prevent homeownership, may be related to contemporary food access and purchasing power.

Figure 3 demonstrates that areas that are USDA-designated food deserts are more commonly located in HOLC tracts designed " $\mathrm{C}$ " and
"D" grades. This figure illustrates how contemporary USDA-designated food deserts-which indicate a prevalence of low-income residents-are spatially linked to historic redlining policies that prevented the accumulation of wealth through homeownership.

Figures 4 and 5 use U.S. Census data to indicate that " $A$ " and " $B$ " tracts remain primarily populated by white residents with higher per-capita income per household. These figures use a visual clustering of contemporary racial/ethnic populations to demonstrate how current residential patterns echo the intentional segregation of redlining policies. This stark visualization of contemporary segregation contributes to an understanding of how the racialized foundations of food apartheid continue to affect intergenerational wealth accumulation and thus food security.

Figure 1. USDA Food Deserts and B.U.G. Farms Community Supported Agriculture Food Distribution

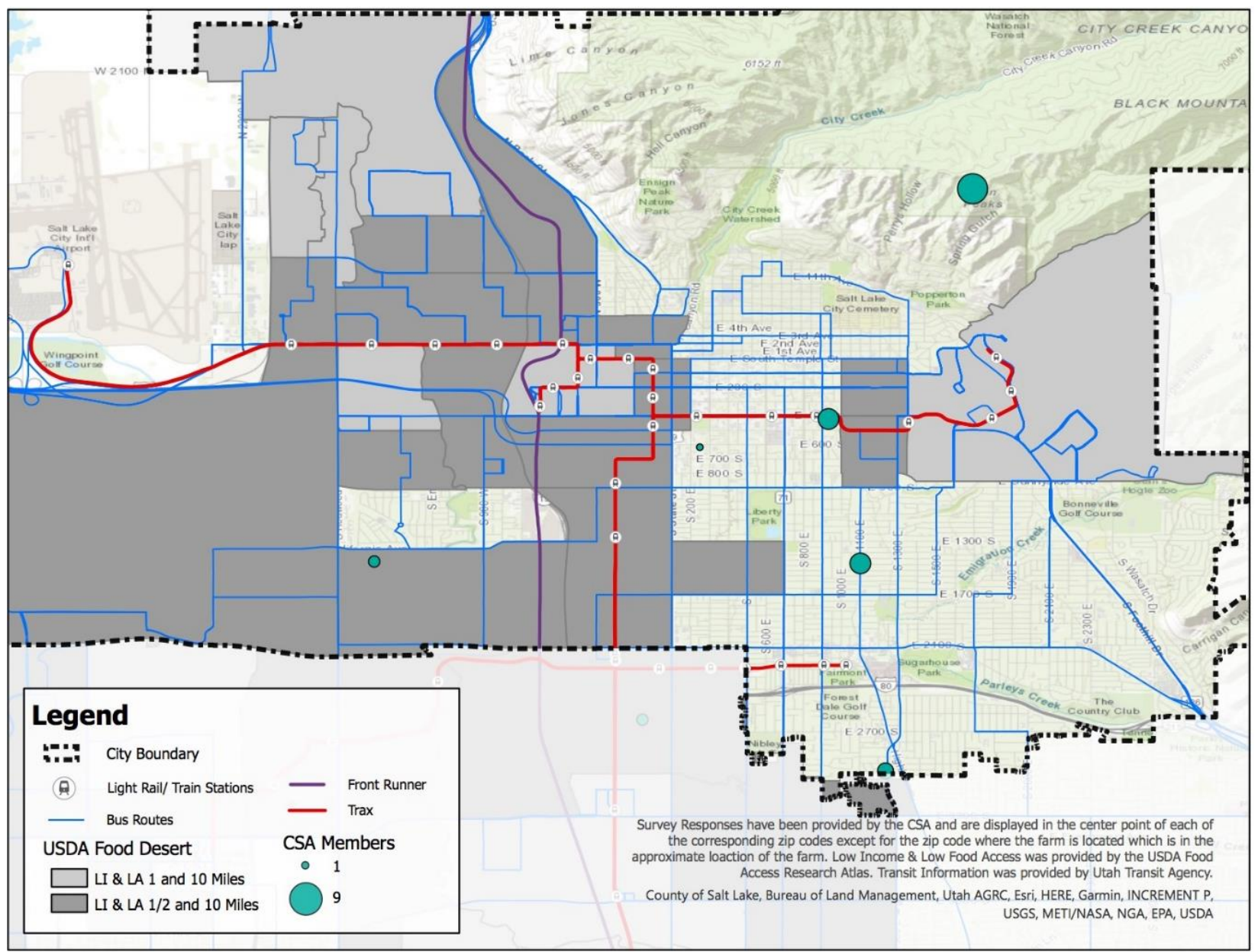


SLC public transportation data included in these figures also indicate a lack of public transportation available in formerly redlined census tracts, which overlaps with contemporary USDA-designated food desert census tracts. Considered together, this collection of figures demonstrates how the ongoing impacts of redlining intertwine with contemporary socioeconomic inequality and food apartheid in SLC. HOLC redline maps of SLC demonstrate that " $\mathrm{D}$ " grade areas, or communities of color, were primarily located in what is contemporarily referred to as the Westside. This is connected to the findings of Cooley (2018), who found that residents in SLC's Westside neighborhoods were less likely to be approved for homeownership loans, contributing to systemic barriers to housing and intergenerational wealth accumulation and has led to continued racial segregation across the city. In an analysis of 2010 ACS data, Cooley (2018) also found that census tracts associated with HOLC "D" or "hazardous" ratings were linked to higher proportions of renter-occupied and vacant units, whereas areas designated " $\mathrm{A}$ " and " $\mathrm{B}$ " continued to reflect higher proportions of owneroccupied housing units.

These figures align with previous research that also suggests that residents of the Westside continue to experience disproportionate impacts to various socioeconomic determinants of health, such as access to health care, transportation, affordable housing, food, and air quality (Mullen et al., 2020; SLC Planning Commission, 2014; Wood et al., 2013).

\section{Figure 2. Homeowners Loan Corporation (HOLC) 1930s Redlining Zones and Distribution of B.U.G. Farms Community Supported Agriculture Members}

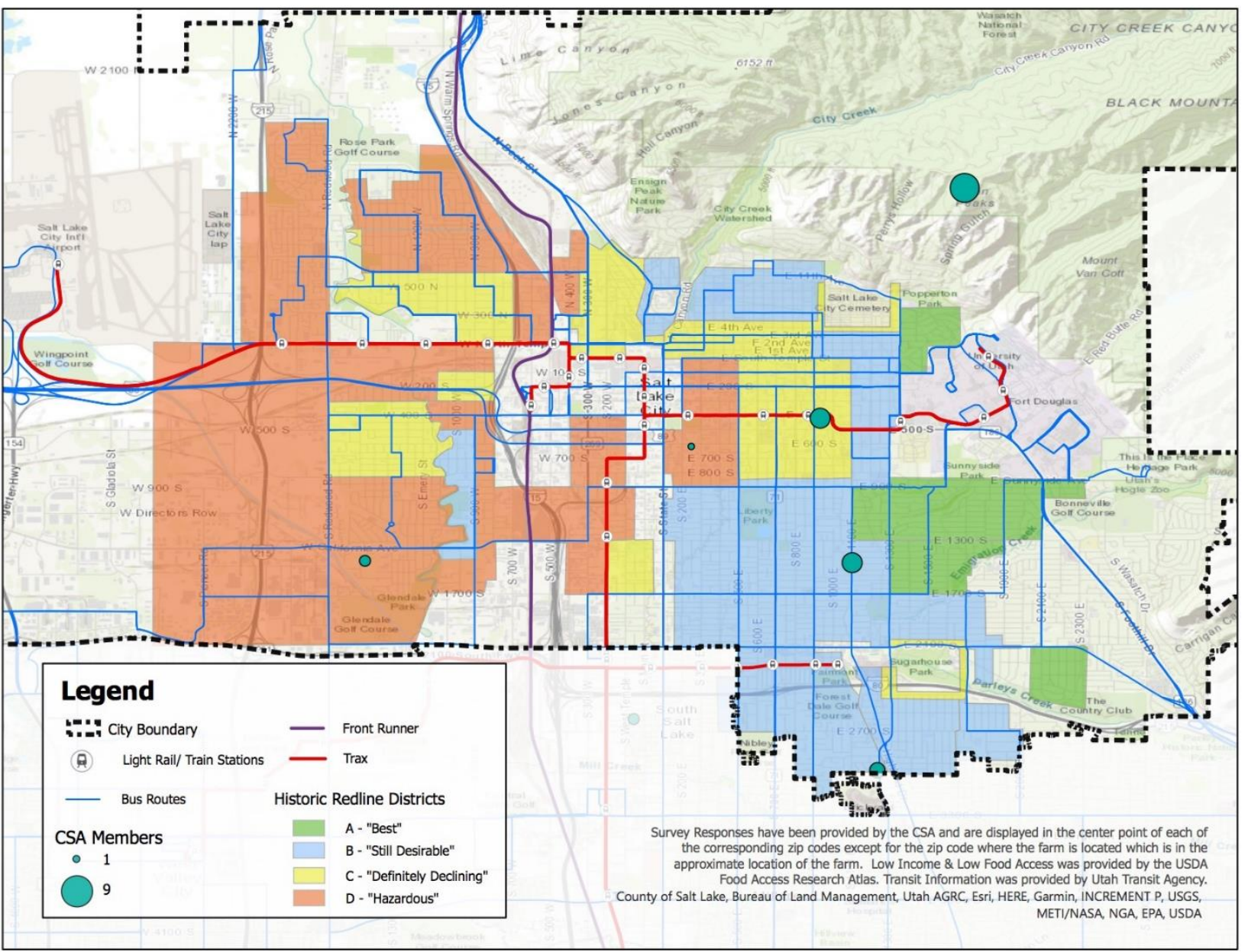




\section{Discussion and Implications}

This study illustrates how the sociopolitical history of SLC and the larger political and economic structures at work throughout the food system complicate the justice-oriented aims of B.U.G. Farms. Geographies of inequity form the backdrop for food apartheid in the Westside and complicate the aims of many UA practitioners who seek to practice food justice. Considered collectively, these figures provide insights into how the impacts of food apartheid also shape the broader relationships between UA and food sovereignty in SLC. Our previous fieldwork indicates that B.U.G. farmers are among several UA practitioners who have been drawn to the Westside to access land affordably. In the case of B.U.G. Farms, the necessity to charge nonsubsidized higher prices to offset the costs of labor-intensive food production likely set the stage for its export of produce from the Westside to CSA members who reside in other, primarily white and more affluent areas of the city with greater access to food. Through interviews with additional UA practitioners in Glendale, we have learned that other farms and gardens experience a similar need to export produce, as the most financially viable markets are located in other areas of the city (Yagüe et al., 2020). These findings offer important considerations for various types of UA operators in SLC's Westside and across the city interested in attending to food justice. This study indicates that racially inequitable access to food across SLC is spatially connected to the effect of residential redlining, which also predicates disparate access to housing and transportation. These findings reso-

Figure 3. U.S. Department of Agriculture (USDA) Food Deserts and Homeowners Loan Corporation (HOLC) Redlining Zones

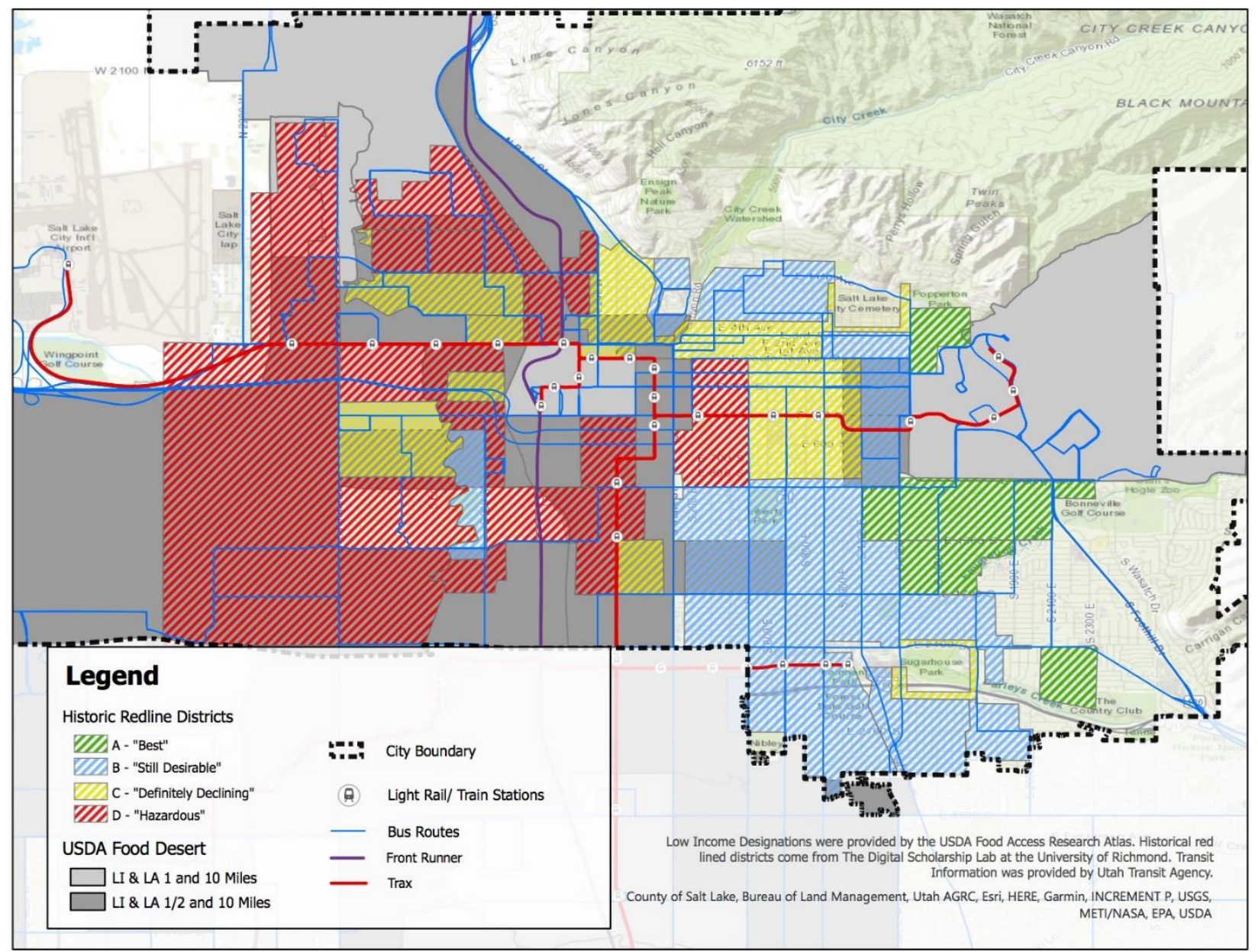


nate with previous research that suggests that populations who qualified for homeownership in nonredlined census tracts continue to hold more access to intergenerational wealth through the accumulation of home equity (McClintock, 2011; Rothstein, 2017). This accumulation of wealth may contribute to an ability to pay the higher costs associated with nonsubsidized, locally produced food such as a CSA membership.

The underlying factors for food security, such as housing and income inequality, cannot be addressed comprehensively through charitable approaches to food security (food banks, soup kitchens, and emergency food assistance) (GainesTurner et al., 2019; Kirkpatrick \& Tarasuk, 2011; Raskind, 2020; Wolf-Powers, 2017). Charity-based emergency food access programs have become a normalized and necessary, yet insufficient, solution to hunger and food-related illness (Fisher, 2017; Poppendieck, 1999). Enduring income inequality in formerly redlined and food apartheid-impacted neighborhoods indicates a need for more comprehensive policies, from raising the minimum wage to housing-first models with robust commitments to food security (Hainstock \& Mesuda, 2019; Housing First Charlotte Mecklenburg, 2020). These justice-focused structural adjustments represent systemic approaches to improving the lives of people at the lower ends of the socioeconomic spectrum. Pertaining particularly to concerns associated with food apartheid, emergency food aid delivered through food banks and federal food assistance programs such as SNAP attend to the immediate symptoms of food injustice. However, in order to increase the feasibility for UA to alleviate food insecurity, a more holistic approach is

\section{Figure 4. Hispanic and Racialized Population Distributions and Redlining}

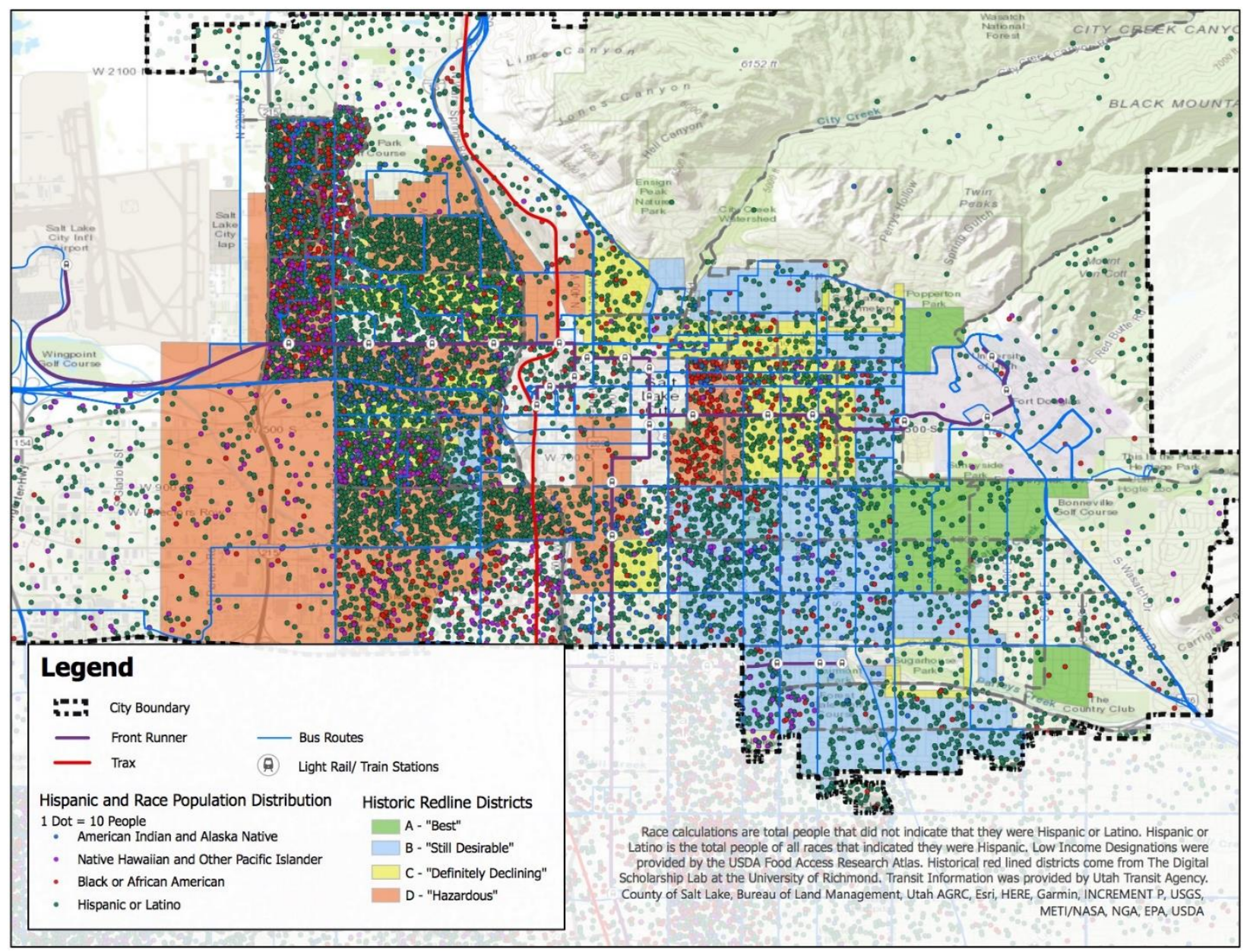


needed to confront the root causes of food apartheid and introduce opportunities to replace emergency food access programs with financially viable and sustainable, community-driven food access and UA initiatives.

The findings of this study are likely connected to the ways in which federally subsidized commodities and labor programs buoy corporate interests in the food system (Windham, 2007). Federally subsidized commodities and labor programs could be adapted to better serve small farms and increase accessibility to marginalized people as consumers and potential producers. Previous research indicates that the redirection of federal subsidies away from corporate interests and toward small farms, UA, and communitycontrolled food provision programs may offer a promising pathway toward food sovereignty through UA at a broad scope (Bruckner, 2016; Fisher, 2017; Graddy-Lovelace \& Diamond, 2017; Holt-Giménez, 2019; Patel, 2012).

Because USDA food desert census tracts are calculated based on access to supermarkets, the correspondence of food desert polygons with HOLC redlined tracts indicates enduring relationships between residential and supermarket redlining, as formerly redlined areas continue to experience less access to supermarkets. However, considering research that indicates the introduction of big-box supermarkets may prime neighborhoods for gentrification and the displacement of independent and community-oriented food outlets (Anguelovski, 2015), we suggest that future food access initiatives in the Westside should focus on investing in currently existing and communitycontrolled food outlets such as regional and family-

\section{Figure 5. White Population Distributions and Redlining}

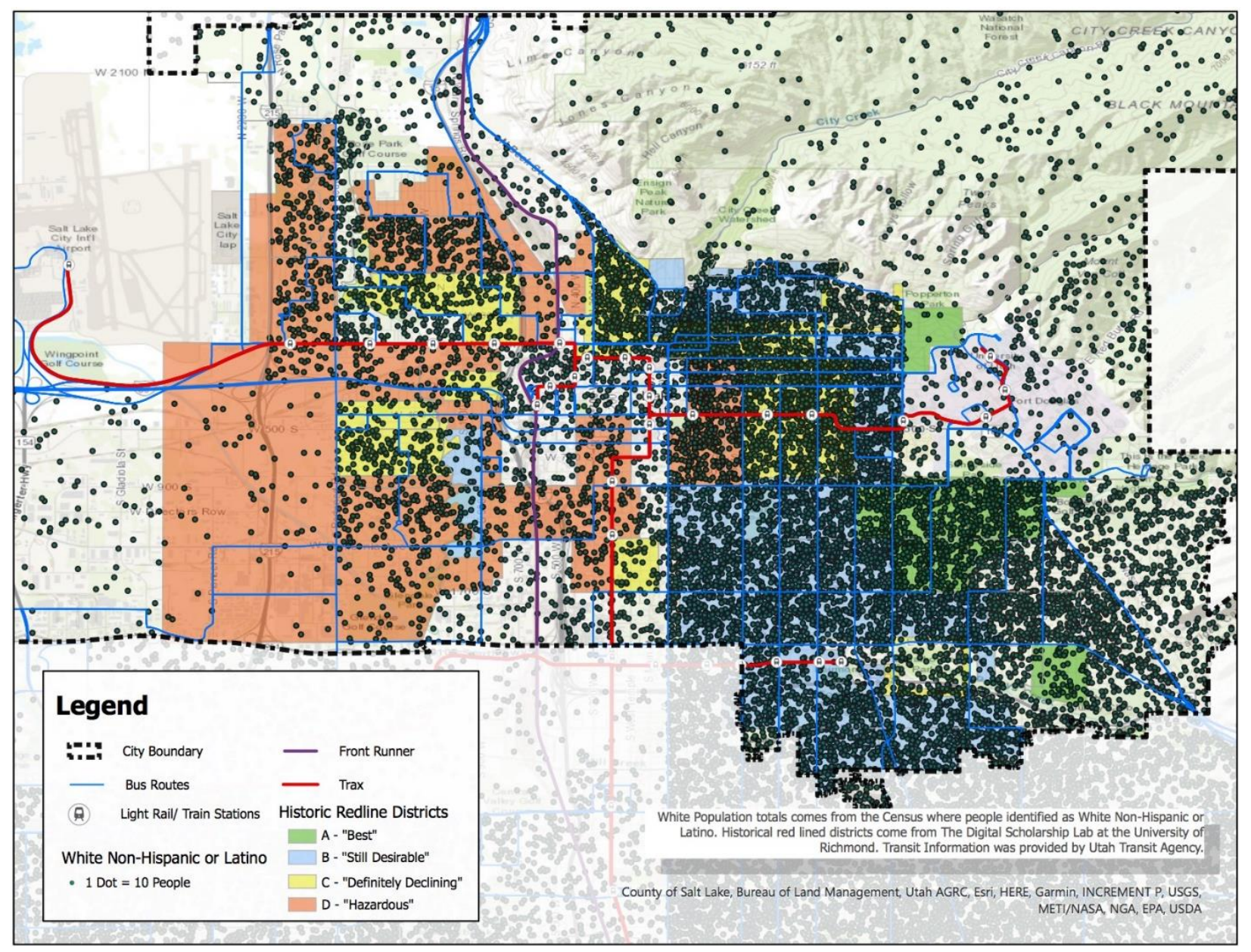


owned businesses, ethnic grocers, small farms or gardens, and local markets.

Our findings also illuminate a lack of access to public transportation in formerly redlined Westside neighborhoods and current USDA-designated food deserts. Strategies that increase equitable public transportation in low-income areas can also increase access to fresh, healthy, and affordable foods (Dutko et al., 2012; MacNell et al., 2017; Strome et al., 2016). Consequently, municipal investment in better public transportation may serve as a tool for increased food access and overall health and well-being in the Westside. One promising step toward this goal is the newly launched Transportation Equity for Salt Lake City's Westside Study, which explores possibilities for increased access to transportation infrastructure throughout the Westside (SLC Transportation, 2021).

Throughout our analysis and discussion, we position food sovereignty as a framework through which to understand food apartheid and identify the need for equity and justice-focused food policies and programs. As a form of decolonization itself, food sovereignty discourse has long been led by Indigenous scholars and activists and is incomplete without a commitment to Indigenous autonomy and reparations (Grey \& Patel, 2014; Whyte, 2017). We acknowledge that a major limitation of this study lies in the inherent relationship between food apartheid and settler colonialism. The localized manifestations of food apartheid that we examine in this manuscript occur on stolen Indigenous land that has been cultivated within the U.S. agricultural system rooted in chattel slavery and displacement of Black, Indigenous, and people of color (Ayazi \& Elsheikh, 2016; Elsheikh, 2016; Fagundes et al., 2020; Penniman, 2018; Tyler \& Moore, 2013). In order to connect UA with the aims of the food sovereignty movement and to alleviate the impacts of food apartheid, we argue that justice-oriented approaches to food system reform must include reparations to displaced and disenfranchised African American and Indigenous peoples, and federal investment in agricultural land preservation and subsidized land access programs for small farmers, especially BIPOC farmers. A promising example of this reparative act has recently been introduced into the U.S. legislature via the Justice for Black Farmers Act (2020), which we identify as an important step toward redressing food apartheid, albeit one that is incomplete without land reparations to Indigenous peoples. The American Rescue Plan is another example of advancement toward equity in national food policy, as it contains a directive for the USDA to establish an equity committee to "address historical discrimination and disparities in the agriculture sector" (USDA, 2021).

This investigation into food apartheid in SLC could not have occurred without the introspection and partnership of the farmers themselves, which provides an example of how food itself can serve as a window into the structural processes that produce food apartheid and spark change toward much needed policy reforms. In this case, the use of critical geographic methods illustrates how food apartheid complicates UA in SLC. The implications of this study are also related to the socio-ecological legacies of inequality that remain prevalent in the Westside and draw attention to the need for future research and programs that apply an environmental justice approach to the interrelated nature of food apartheid amidst social disparities that compound as imminent threats to overall health and wellbeing. Salt Lake City has taken significant steps toward these goals by establishing a Resident Equity Food Advisors program (RFEA), consisting of a group of residents from marginalized backgrounds who provide counsel to the city on issues relating to food access and equity. The first cohort of the RFEA program has called for two key actions related to the findings of this study: (1) The launch of a community food assessment update that centers equity in its scope, process, and outcomes; and (2) a resolution from the mayor and city council declaring Salt Lake City's commitment to advancing food equity and increasing access to healthy food for all residents (SLC Department of Sustainability, 2021).

One of the ongoing outcomes of this praxis is our collaboration with the SLC Food Policy Council to share the findings of this study, which may be relevant to the proposed community food assessment. Our research team continues to support B.U.G. Farms' goals of making food more readily 
available in the Westside. The farm remains committed to increasing community engagement through local hiring practices, knowledge-sharing with nearby community garden projects, donating produce and creating sales agreements with local food pantries and community kitchens. B.U.G. farmers are pursuing the option to accept EBT payments for CSA shares by 2022, and, along with their plans to continue working with other farms on food justice and security issues, are exploring the option to implement a mobile bike farmstand that would enable the sale of produce beyond CSA shares.

Our future research will explore how farms and food-access organizations can employ collaborative praxis in order to avoid introducing outsider or top-down approaches to food access. This study also provides a framework for our ongoing partnerships with Westside community groups as we seek to collaboratively forge educational pathways through UA and food sovereignty praxis. However, the greater pursuit of food sovereignty in SLC's Westside and elsewhere must include broad-scale work to establish equitable housing policies that create pathways to homeownership specifically for BIPOC, increase public transportation, and increase minimum wages (Gaines-Turner et al., 2019; Karpman et al., 2018, Kirkpatrick \& Tarasuk, 2011; Mee et al., 2014, Raskind, 2020; WolfPowers, 2017). Herein lies the power of praxis, given that "educational institutions are often community hubs with considerable political and social capital, [where] institution-wide measures that enable students to participate [in collective action] hold great promise in higher education institutions overall" (Verlie et al., 2021, p. 144).

Ultimately, this work arises out of an imperative for food systems activists, scholars, and advocates, including farmers, to interrogate the racially uneven geographies of access in our communities. We recognize that the fundamental political econ- omy of the broader food system can, by design, prevent small farmers from attending to much more than the already daunting task of growing food in a system that is stacked against alternative food provision. Yet, partnerships in praxis can build capacity to overcome these constraints and create opportunities to investigate, and thus disrupt, the racial hierarchies enmeshed in federal agricultural policy, municipal zoning, and residential homeownership programs that perpetuate food apartheid.

\section{Acknowledgments}

This research would not have been possible without the collaboration of our community partners at B.U.G. Farms, to whom we are deeply thankful for undertaking this journey of learning with us. We are also grateful to the many community members, leaders, and organizations who have shared their perspectives with us and been supportive partners throughout this research. This includes the University of Utah Neighborhood Partners, which supported community outreach; the University of Utah Bennion Center and SPARC Environmental Justice Lab, which supported community engaged learning student projects; the University of Utah Sustainability Office, which has supported this project through the Sustainable Campus Initiative Fund green grants program; the Glendale Mountain-View Community Learning Center, which invited us to community events; and the Edible Campus Gardens for connecting this research with our campus community. We also thank the many students who have worked in various phases of this project, and specifically students enrolled in the Fall 2018 and Fall 2021 ENVST 5558 Food for Justice, Health and Sustainability Courses, and Fall 2020 ENVST 3365 Environmental Justice Course. Finally, we thank GIS specialist Walter K. Jenkins (https://www.walterkjenkins.com; @AvidDabbler) for partnership and production of Figures 1-5.

\section{References}

Agyeman, J., \& McEntee, J. (2014). Moving the field of food justice forward through the lens of urban political ecology. Geography Compass, 8(3), 211-220. https://doi.org/10.1111/gec3.12122

Alkon, A., \& Agyeman, J. (2011). Cultivating food justice: Race, class, and sustainability. The MIT Press. https://doi.org/10.7551/mitpress/8922.001.0001 
Alkon, A. H., Cadji, Y. J., \& Moore, F. (2019). Subverting the new narrative: Food, gentrification and resistance in Oakland, California. Agriculture and Human Values, 36, 793-804. https://doi.org/10.1007/s10460-019-09954-x

Alkon, A., \& McCullen, C. G. (2011). Whiteness and farmers markets: Performances, perpetuations ... contestations? Antipode, 43(4), 937-959. https://doi.org/10.1111/j.1467-8330.2010.00818.x.

Alkon, A., \& Norgaard, K. (2009). Breaking the food chains: An investigation of food justice activism. Sociological Inquiry, 79(3), 289-305. https://doi.org/10.1111/j.1475-682X.2009.00291.x

Alkon, A., Yuki, K., \& Sbicca, J. (Eds.). (2020). A recipe for gentrification: Food, power, and resistance in the city. New York University Press. https://doi.org/10.18574/nyu/9781479834433.001.0001

Altieri, M. A. (2008). Small farms as a planetary ecological asset: Five key reasons why we should support the revitalisation of small farms in the Global South. Third World Network. https://twn.my/title/end/pdf/end07.pdf

Anguelovski, I. (2015). Alternative food provision conflicts in cities: Contesting food privilege, injustice, and whiteness in Jamaica Plain, Boston. Geoforum, 58, 184-194. https://doi.org/10.1016/j.geoforum.2014.10.014

Ayazi, H., \& Elsheikh, E. (2016). The U.S. farm bill: Corporate power and structural racialization in the United States food system. https://haasinstitute.berkeley.edu/sites/default/files/haasinstitutefarmbillreport publish 0.pdf

Bauer, M., \& Stewart, M. (2013). Close to slavery: Guestworker programs in the United States (2013 Edition). Southern Poverty Law Center. https://www.splcenter.org/sites/default/files/d6 legacy files/downloads/publication/SPLC-Closeto-Slavery-2013.pdf

Bekkerman, A., Belasco, E. J., Smith, \& V. H. (2019). Does farm size matter? Distribution of crop insurance subsidies and government program payments across U.S. farms. Applied Economic Perspectives and Policy, 41(3), 498-518. https://doi.org/10.1093/aepp/ppy024

Bosco, F. J., \& Joassart-Marcelli, P. (2018). Relational space and place and food environments: Geographic insights for critical sustainability research. Journal of Environmental Studies and Sciences, 8(4), 539-546.

https://doi.org/10.1007/s13412-018-0482-9

Brones, A. (2018, May 7). Karen Washington: It's not a food desert, it's food apartheid. Guernica. https://www.guernicamag.com/karen-washington-its-not-a-food-desert-its-food-apartheid/

Brown, S., \& Getz, C. (2011). Farm worker food insecurity and the production of hunger in California. In A. Alkon \& J. Agyeman (Eds.), Cultivating food justice: Race, class, and sustainability (pp. 121-146). The MIT Press.

Bruckner, T. (2016), Agricultural subsidies and farm consolidation. American Journal of Economic Sociology, 75, 623-648. https://doi.org/10.1111/ajes.12151

Cachelin, A., Ivkovich, L., Jensen, P., \& Neild, M. (2019). Leveraging foodways for health and justice. Local Environment, 24(5), 417-427. https://doi.org/10.1080/13549839.2019.1585771

Carothers, T. L. (2018). Justice and the river: Community connections to an impaired urban river in Salt Lake City. https://digitalcommons.usu.edu/etd/7381

Center on Budget and Policy Priorities. (2019). Chart book: SNAP helps struggling families put food on the table. https://www.cbpp.org/sites/default/files/atoms/files/3-13-12fa-chartbook.pdf

Coalition of Immokalee Workers. (2020). Slavery in the fields and the food we eat. Retrieved December 7, 2020, from https://ciw-online.org/slavery/

Community Research Collaborative. (2021). In it together: Community-based research guidelines for communities and higher education. University of Utah.

Cooksey Stowers, K., Jiang, Q., Atoloye, A., Lucan, S., \& Gans, K. (2020). Racial differences in perceived food swamp and food desert exposure and disparities in self-reported dietary habits. International Journal of Environmental Research and Public Health, 17(19), Article 7143. https://doi.org/10.3390/ijerph17197143

Cooley, A. (2018). Socioeconomic outcomes of redlining in Salt Lake City, Utah [Research poster presentation]. Weber State University. https://cdn.filestackcontent.com/qjEaoEvgQnaA6m7CT6SA

Corcoran, M. P. (2021). Beyond "food apartheid": Civil society and the politicization of hunger in New Haven, Connecticut. Urban Agriculture and Regional Food Systems, 6, Article e20013. https://doi.org/10.1002/uar2.20013

Cross, J. L. (2020). Labor use and labor challenges faced by small fruit and vegetable farms: The case of Tennessee. Haslam Scholars Projects, University of Tennessee. https://trace.tennessee.edu/utk haslamschol/10 
De Master, K. T., \& Daniels, J. (2019). Desert wonderings: Reimagining food access mapping. Agriculture and Human Values, 36(2), 241-256. https://doi.org/10.1007/s10460-019-09914-5

Denzin, N. K. (1978). The research act: A theoretical introduction to sociological methods. McGraw-Hill.

Dutko, P., Ver Ploeg, M., \& Farrigan, T. (2012). Characteristics and influential factors of food deserts (Report No. ERR-140). U.S. Department of Agriculture, Economic Research Service. https://www.ers.usda.gov/webdocs/publications/45014/30940 err140.pdf

Eisenhauer, E. (2001). In poor health: Supermarket redlining and urban nutrition. GeoJournal, 53(2), $125-133$. https://doi.org/10.1023/A:1015772503007

Elsheikh, E. (2016). Race and corporate power in the U.S. food system: Examining the farm bill. Dismantling Racism in the Food System, 2, 1-7. https:// foodfirst.org/wp-content/uploads/2016/06/DRnumber2 VF.pdf

Fagundes, C., Picciano, L., Tillman, W., Mleczko, J., Schwier, S., Graddy-Lovelace, G., Hall, F., \& Watson, T. (2020). Ecological costs of discrimination: Racism, red cedar and resilience in farm bill conservation policy in Oklahoma. Renewable Agriculture and Food Systems, 35(4), 420-434. https://doi.org/10.1017/S1742170519000322

Farmers Market Coalition. (2020). Supplemental Nutritional Assistance Program. https:// farmersmarketcoalition.org/advocacy/snap/

Feeding America. (2020). Hunger in America. https://www.feedingamerica.org/hunger-in-america

Fielding, J. E., \& Simon, P. A. (2011). Food deserts or food swamps? Comment on "Fast Food Restaurants and Food Stores." Archives of Internal Medicine (1960), 171(13), 1171-1172. https://doi.org/10.1001/archinternmed.2011.279

Fisher, A. (2017). Big hunger: The unholy alliance between corporate America and anti-hunger groups. The MIT Press. https://doi.org/10.7551/mitpress/10987.001.0001

Friedmann, H. (1993). The political economy of food: A global crisis. New Left Review, 197, 29-57.

Gaines-Turner, T., Simmons, J. C., \& Chilton, M. (2019). Recommendations from SNAP participants to improve wages and end stigma. American Journal of Public Health (1971), 109(12), 1664-1667. https://doi.org/10.2105/AJPH.2019.305362

Graddy-Lovelace, G., \& Diamond, A. (2017). From supply management to agricultural subsidies—and back again? The U.S. farm bill \& agrarian (in)viability. Journal of Rural Studies, 50, 70-83. https://doi.org/10.1016/j.jrurstud.2016.12.007

Grey, S., \& Patel, R. (2014). Food sovereignty as decolonization: Some contributions from Indigenous movements to food system and development politics. Agriculture and Human V alues, 32(3), 431-444. https://doi.org/10.1007/s10460-014-9548-9

Gripper, A. (2020). We don't farm because it's trendy; we farm as resistance, for healing and sovereignty. Environmental Health News. Retrieved December 7, 2020, from https://www.ehn.org/black-farming-food-sovereignty-2645479216.html

Guthman, J. (2008a). "If they only knew": Color blindness and universalism in California alternative food institutions. The Professional Geographer, 60(3), 387-397. https://doi.org/10.1080/00330120802013679

Guthman, J. (2008b). Bringing good food to others: Investigating the subjects of alternative food practice. Cultural Geographies, 15(4), 431-447. https://doi.org/10.1177/1474474008094315

Hainstock, M., \& Masuda, J. R. (2019). "We have a roof over our head, but we have to eat too": Exploring shifting foodscapes from homelessness into Housing First in Kingston, Ontario. Health \& Place, 59, 102-197. https://doi.org/10.1016/i.healthplace.2019.102197

Heynen, N. (2009). Bending the bars of empire from every ghetto for survival: The Black Panther Party's radical antihunger politics of social reproduction and scale. Annals of the Association of American Geographers, 99(2), 406-422. https://doi.org/10.1080/00045600802683767

Hoffpauir, J. (2009). The environmental impact of commodity subsides: Nepa and the farm bill. Fordham Environmental Law Review, 20(1), 233-266.

Holt-Gimenez, E. (2009). From food crisis to food sovereignty: The challenge of social movements. Monthly Review (New York. 1949), 61(3), 142. https://doi.org/10.14452/MR-061-03-2009-07 11

Holt-Giménez, E. (2019). Can we feed the world without destroying it? Polity Press.

Holt-Giménez, E., \& Harper, B. (2016). Food systems racism: From mistreatment to transformation. Food First 1(2), 1-7. 
Holt-Giménez, E., \& Shattuck, A. (2011). Food crises, food regimes and food movements: Rumblings of reform or tides of transformation? The Journal of Peasant Studies, 38(1), 109-144. https://doi.org/10.1080/03066150.2010.538578

Hoover, B. (2013). White spaces in Black and Latino places: Urban agriculture and food sovereignty. Journal of Agriculture, Food Systems, and Community Development, 3(4), 109-115. https://doi.org/10.5304/jafscd.2013.034.014

Housing First Charlotte Mecklenburg. (2020). Housing First Charlotte-Mecklenburg Research \& Evaluation Project. Final report. Retrieved December 14, 2020, from https://ui.uncc.edu/sites/ui.uncc.edu/files/media/HFCM\%20Final\%20Outcomes\%20Report\%202020-Final.pdf

Horst, M., McClintock, N., \& Hoey, L. (2017). The intersection of planning, urban agriculture, and food justice: A Review of the literature. Journal of the American Planning Association, 83(3), 277-295. https://doi.org/10.1080/01944363.2017.1322914

Institute for Agriculture \& Trade Policy. (2012). Draft principles of food justice. Retrieved December 14, 2020, from https://www.iatp.org/documents/draft-principles-of-foodjustice\#: :text=Food $\% 20$ justice $\% 20$ is $\% 20$ the $\% 20$ right,Includes $\% 3$ A\&text $=$ Gender $\% 20$ equity

Jettner, J. F. (2017). Community gardens: Exploring race, racial diversity and social capital in urban food deserts [Doctoral dissertation, Virginia Commonwealth University]. https://doi.org/10.25772/KJPK-2J80

Justice for Black Farmers Act, S.L.C. RYA20816 V50, 116 th Congress (2020). https://www.booker.senate.gov/imo/media/doc/Justice $\% 20$ for $\% 20$ Black $\% 20$ Farmers $\% 20$ Act $\% 20$ of $\% 202020 \% 2$ OBill.pdf

Karpman, M., Zuckerman, S., \& Gonzalez, D. (2018). The Well-Being and Basic Needs Survey: A new data source for monitoring the health and well-being of individuals and families. Urban Institute. https://www.urban.org/sites/default/files/publication/98919/the well-being and basic needs survey 1.pdf

Kellegrew, K., Powers, A., Struempler, B., Parmer, S., Funderburk, K., Griffin, J., \& Tran, C. (2018). Evaluating barriers to SNAP/EBT acceptance in farmers markets: A survey of farmers. Journal of Agriculture, Food Systems, and Community Development, 8(1), 1-14. https://doi.org/10.5304/jafscd.2018.081.010

Kellner, G. C. (2016). Growing food security: The impact of community gardens on food security in Denver, Colorado [Master's thesis, University of Denver]. https://digitalcommons.du.edu/etd/1159

Kirkpatrick, S., \& Tarasuk, V. (2011). Housing circumstances are associated with household food access among lowincome urban families. Journal of Urban Health, 88(2), 284-296. https://doi.org/10.1007/s11524-010-9535-4

Larimore, S. (2017). Cultural boundaries to access in farmers markets accepting Supplemental Nutrition Assistance Program (SNAP). Qualitative Sociology, 41(1), 63-87. https://doi.org/10.1007/s11133-017-9370-y

Lemke, S., \& Delormier, T. (2018). Indigenous Peoples' food systems, nutrition, and gender: Conceptual and methodological considerations. Maternal \& Child Nutrition, 13(S3), Article e12499. https://doi.org/10.1111/mcn.12499

Leslie, I., Wypler, J., \& Bell, M. (2019). Relational agriculture: Gender, sexuality, and sustainability in U.S. farming. Society \& Natural Resources, 32(8), 853-874. https://doi.org/10.1080/08941920.2019.1610626

Lewis, D. (2015). Gender, feminism and food studies: A critical review. African Security Review, 24(4), 414-429. https://doi.org/10.1080/10246029.2015.1090115

MacNell, L., Elliott, S., Hardison-Moody, A., \& Bowen, S. (2017). Black and Latino urban food desert residents' perceptions of their food environment and factors that influence food shopping decisions. Journal of Hunger \& Environmental Nutrition, 12(3), 375-393. https://doi.org/10.1080/19320248.2017.1284025

Manning, R. (2004). The oil we eat: Following the food chain back to Iraq [Essay]. Harper's Magazine, 308(1845), 37.

Manyise, T., \& Dentoni, D. (2021). Value chain partnerships and farmer entrepreneurship as balancing ecosystem services: Implications for agri-food systems resilience. Ecosystem Services, 49, Article 101279. https://doi.org/10.1016/j.ecoser.2021.101279

Martínez-Torres, M., \& Rosset, P. (2010). La Vía Campesina: The birth and evolution of a transnational social movement. The Journal of Peasant Studies, 37(1), 149-175. https://doi.org/10.1080/03066150903498804

McClintock, N. (2011). From industrial garden to food desert. In A. Alkon \& J. Agyeman (Eds.), Cultivating food justice: Race, class, and sustainability (pp. 89-120). The MIT Press. 
McClintock, N. (2018). Urban agriculture, racial capitalism, and resistance in the settler-colonial city. Geography Compass, 12(6). https://doi.org/10.1111/gec3.12373

McKellar, K. (2015, August 17). West-side SLC residents, Democrats join fight against prison move. KSL News. https://www.ksl.com/article/36012277/west-side-slc-residents-democrats-join-fight-against-prison-move

McMichael, P. (2009). A food regime genealogy. The Journal of Peasant Studies, 36(1), 139-169. https://doi.org/10.1080/03066150902820354

Mee, K. J., Instone, L., Williams, M., Palmer, J., \& Vaughan, N. (2014). Renting over troubled waters: An urban political ecology of rental housing. Geographical Research, 52(4), 365-376. https://doi.org/10.1111/1745-5871.12058

Mullen, C., Grineski, S., Collins, T., Xing, W., Whitaker, R., Sayahi, T., \& Kelly, K. (2020). Patterns of distributive environmental inequity under different PM2.5 air pollution scenarios for Salt Lake County public schools. Environmental Research, 186, Article 109543. https://doi.org/10.1016/i.envres.2020.109543

Neff, R., Palmer, A. M., McKenzie, S. E., \& Lawrence, R. S. (2009). Food systems and public health disparities. Journal of Hunger \& Environmental Nutrition, 4(3-4), 282-314. https:/ / doi.org/10.1080/19320240903337041

Nelson, R. K., \& Ayers, E. L. (2020). Mapping inequality: Redlining in New Deal America. American Panorama. Digital Scholarship Lab, University of Richmond. Retrieved November 28, 2020, from https://dsl.richmond.edu/panorama/redlining/

Nyéléni. (2007). Nyéléni Forum For Food Sovereignty Declaration. https://nyeleni.org/DOWNLOADS/Nyelni EN.pdf

Oberholtzer, L., \& Project, S. F. S. (2004). Community supported agriculture in the Mid-Atlantic region. Results of a shareholder survey and farmer interviews. Small Farm Success Project. https://www.scribd.com/document/7806331/community-supported-agriculture-in-the-mid-atlantic-region\#

Olson, L. (2018). Great west food desert: City seeks to improve food options on Westside. Utah Stories. https://utahstories.com/2018/06/great-west-food-desert-city-seeks-to-improve-food-options-on-westside/

Patel, R. (2012). Stuffed and starved: The hidden battle for the world food system. Melville House.

Penniman, L. (2018). Farming while Black. Chelsea Green Publishing.

Poppendieck, J. (1999). Sweet charity: Emergency food and the end of entitlement. Penguin Books.

Pride, T. (2016). Resident-led urban agriculture and the hegemony of neoliberal community development: Ecogentrification in a Detroit neighborhood [Doctoral dissertation, Wayne State University]. https://digitalcommons.wayne.edu/oa dissertations/1475

Raja, S., Changxing M., \& Yadav, P. (2008). Beyond food deserts. Journal of Planning Education and Research, 27(4), 469-482. https://doi.org/10.1177/0739456X08317461

Raskind, I. G. (2020). Hunger does discriminate: Addressing structural racism and economic inequality in food insecurity research. American Journal of Public Health (1971), 110(9), 1264-1265. https://doi.org/10.2105/AJPH.2020.305841

Reese, A. M. (2019). Black food geographies: Race, self-reliance, and food access in Washington, D.C. The University Of North Carolina Press. https://doi.org/10.5149/northcarolina/9781469651507.001.0001

Reno, E. (2020). The myth that farmers are well fed, and the reality of food insecurity among Vermont's agricultural laborers [Book review]. Journal of Agriculture, Food Systems, and Community Development, 9(3), 331-332. https://doi.org/10.5304/jafscd.2020.093.025

Reynolds, K., \& Cohen, N. (2016). Beyond the kale: Urban agriculture and social justice activism in New York. City. University of Georgia Press.

Ricciardi, V., Mehrabi, Z., Wittman, H., James, D., \& Ramankutty, N. (2021). Higher yields and more biodiversity on smaller farms. Nature Sustainability, 4, 651-657. https://doi.org/10.1038/s41893-021-00699-2

Rose, D., Bodor, J. N., Swalm, C. M., Rice, J. C., Farley, T. A., \& Hutchinson, P. L. (2009). Deserts in New Orleans? Illustrations of urban food access and implications for policy. University of Michigan National Poverty Center and USDA Economic Research Service.

Rose, J., \& Johnson, C. (2020). Contextualizing reliability and validity in qualitative research: Toward more rigorous and trustworthy qualitative social science in leisure research. Journal of Leisure Research, 51(4), 432-451. https://doi.org/10.1080/00222216.2020.1722042

Rothstein, R. (2017). The color of law: A forgotten history of how our government segregated America (First ed.). Liveright. 
Salt Lake City Department of Sustainability. (2021). Salt Lake City Resident Food Equity Advisors, final recommendations (Report produced by Carbaugh Associates, Inc.). http://www.slcdocs.com/slcgreen/Food/2021 RFEA Recommendations.pdf

Salt Lake City Planning Commission. (2014). The Westside master plan. http://www.slcdocs.com/Planning/MasterPlansMaps/WSLMPA.pdf

Salt Lake City Schools. (n.d.). Glendale Middle School community involvement. Retrieved February 2022 from https://glendale.slcschools.org/academics/curriculum-departments/community-involvement

Salt Lake City Transportation [SLC Transportation]. Westside Transportation Equity Study. Accessed October 4, 2021, from https://www.slc.gov/transportation/plans-studies/westside-equity/

Salt Lake County Health Department. (2017). 2017 Salt Lake County community health assessment. http://www.healthysaltlake.org/content/sites/saltlake/Documents/Community Health Assessment.pdf

Savin-Baden, M., \& Major, C. H. (2013). Qualitative research: The essential guide to theory and practice. Routledge.

Sbicca, J. (2012). Growing food justice by planting an anti-oppression foundation: Opportunities and obstacles for a budding social movement. Agriculture and Human Values, 29(4), 455-466. https://doi.org/10.1007/s10460-012-9363-0

Sbicca, J. (2019), Urban agriculture, revalorization, and green gentrification in Denver, Colorado. In T. Bartley (Ed.), The politics of land (pp. 149-170). Emerald Publishing. https://doi.org/10.1108/S0895-993520190000026011

Sbicca, J. (2020). The urban agriculture fix: Navigating displacement in Denver. In A. Alkon, K. Yuki, \& J. Sbicca (Eds.). (2020). A recipe for gentrification: Food, power, and resistance in the city (pp. 93-110). New York University Press. https://doi.org/10.18574/nyu/9781479834433.003.0005

Sbicca, J., Minkoff-Zern, L. A., \& Coopwood, S. (2020). "Because they are connected": Linking structural inequalities in farmworker organizing. Human Geography, 13(3), 263-276. https://doi.org/10.1177/1942778620962045

Shannon, J. (2013). Rethinking food deserts: The practice and politics of food access [Doctoral dissertation, University of Minnesota]. University of Minnesota Digital Conservancy. https://hdl.handle.net/11299/174891

Shiva, V. (2005). Earth democracy, justice, and peace. Southend Press. https://doi.org/10.5040/9781350219755

Siegner, A., Sowerwine, J., \& Acey, C. (2018). Does urban agriculture improve food security? Examining the nexus of food access and distribution of urban produced foods in the United States: A systematic review. Sustainability, 10(9), Article 2988. https://doi.org/10.3390/su10092988

Slocum, R. (2007). Whiteness, space and alternative food practice. Geoforum, 38(3), 520-533. https://doi.org/10.1016/i.geoforum.2006.10.006

Strome, S., Johns, T., Scicchitano, M., \& Shelnutt, K. (2016). Elements of access: The effects of food outlet proximity, transportation, and realized access on fresh fruit and vegetable consumption in food deserts. International Quarterly of Community Health Education, 37(1), 61-70. https://doi.org/10.1177/0272684X16685252

Taylor, D. E., \& Ard, K. J. (2017). Food availability and the food desert frame in Detroit: An overview of the city's food system. Environmental Practice, 17(2), 102-133. https://doi.org/10.1017/S1466046614000544

Tornaghi, C. (2014). Critical geography of urban agriculture. Progress in Human Geography, 38(4), 551-567. https://doi.org/10.1177/0309132513512542

Torre, M. E., Stoudt, B. G. Manoff, E., \& Fine, M. (2018). Critical participatory action research on state violence. In N. K. Denzin \& Y. S. Lincoln. The Sage Handbook of Qualitative Research (Fifth ed.) (pp. 195-213). SAGE.

Trauger, A. (2017). We want land to live: Making political space for food sovereignty. University of Georgia Press.

Tuck, E. (2009). Suspending damage: A letter to communities [Essay]. Harvard Educational Review, 79(3), $409-428$. https://doi.org/10.17763/haer.79.3.n0016675661t3n15

Tucker, K. (2019). Utah's inland port: Assessing the economic and political impact of a commercial hub in the epicenter of the expanding Wasatch Front. Hinckley Journal of Politics, 20, 35-45.

Tyler, S., \& Moore, E. (2013). Plight of Black farmers in the context of USDA farm loan programs. Professional Agricultural Workers Journal, 1(1), 6-11.

https://ageconsearch.umn.edu/record/236726/files/Shakara\%20S.\%20Tyler.pdf 
U.S. Census Bureau. (2018). American Community Survey 5-year estimates. Retrieved from Census Reporter Profile page for Census Tract 1012, Salt Lake, UT http:/ / censusreporter.org/profiles/14000US49035101200-census-tract-1012-salt-lake-ut/

U.S. Census Bureau. (2020). Supplemental Nutrition Assistance Program (SNAP) receipt for households: 2018. American Community Survey Briefs. https://www.census.gov/content/dam/Census/library/publications/2020/demo/acsbr20-01.pdf

U.S. Department of Agriculture [USDA]. (2020). Visa program. Retrieved December 7, 2020, from https://www.farmers.gov/manage/h2a

USDA. (2021). USD A announces intent to establish an equity commission, solicits nominations for membership (Press Release No. 0207.21). https://www.usda.gov/media/press-releases/2021/09/24/usda-announces-intent-establish-equitycommission-solicits

USDA Economic Research Service [USDA ERS]. (2020). Farm household income estimates. Retrieved December 6, 2020, from https://www.ers.usda.gov/topics/farm-economy/farm-household-well-being/farm-household-income-estimates/

USDA ERS. (2021a). Food Access Research Atlas. https://www.ers.usda.gov/data-products/food-access-research-atlas/

USDA ERS. (2021b). Food Access Research Atlas Documentation. https://www.ers.usda.gov/data-products/food-access-research-atlas/documentation

University Neighborhood Partners. (2019). Neighborhoods. https://partners.utah.edu/about-unp/neighborhoods/

Utah Transit Authority. (2020). Salt Lake County system map. Retrieved November 28, 2020, from https://www.rideuta.com/-/media/Files/System-Maps/2020/AUG 2020 SL System Map.ashx

Verlie, B., Clark, E., Jarrett, T., \& Supriyono, E. (2021). Educators' experiences and strategies for responding to ecological distress. Australian Journal of Environmental Education 37(2), 132-146. https://doi.org/10.1017/aee.2020.34

Walker, R. E., Keane, C. R., \& Burke, J. G. (2010). Disparities and access to healthy food in the United States: A review of food deserts literature. Health \& Place, 16(5), 876-884. https://doi.org/10.1016/i.healthplace.2010.04.013

Wekerle, G. R. G., \& Classens, M. (2015). Food production in the city: (Re)negotiating land, food and property. Local Environment, 20(10), 1175-1193. https://doi.org/10.1080/13549839.2015.1007121

Whyte, K. P. (2017). Indigenous food sovereignty, renewal and US settler colonialism. In M. C. Rawlinson \& C. Ward (Eds.), The Routledge Handbook of Food Ethics (pp. 354-365). Routledge.

Windham, J. S. (2007). Putting your money where your mouth is: Perverse food subsidies, social responsibility \& America's 2007 farm bill. Environmental Law and Policy Journal University of California, Davis, 31(1), 1-33. https://environs.law.ucdavis.edu/volumes/31/1/windham.pdf

Wolf-Powers, L. (2017). Food deserts and real-estate-led social policy. International Journal of Urban and Regional Research, 41(3), 414-425. https://doi.org/10.1111/1468-2427.12515

Wood, J., Downen, J., Benway, DJ., \& Li, D. (2013). Salt Lake County: Fair Housing Equity Assessment and Regional Analysis of Impediments. David Eccles School of Business, University of Utah. https://slco.org/globalassets/1-sitefiles/housing-community-development/files/fairhousingequityassessment-regionalanalysisofimpediments.pdf

Yagüe, B., Joyner, L., Cachelin, A., Lackey, Q., Unruh, S., Maack, L., \& Wason, P. (2020). Urban farms and food access in the Glendale Community (Project report prepared for Backyard Urban Gardens). University of Utah.

Zhang, M., \&, Ghosh, D. (2016). Spatial supermarket redlining and neighborhood vulnerability: A case study of Hartford, Connecticut. Transactions in GIS, 20(1), 79-100. https://doi.org/10.1111/tgis.12142 